\title{
ELASTIC-WAVE AND RELATED PROPERTIES OF CLASTIC ROCKS FROM A PART OF NIGER DELTA, NIGERIA
}

\author{
Olowokere M. T. \\ Department of Applied Geophysics, Federal University of Technology, P. M. B. 704, Akure, Nigeria
}

\begin{abstract}
Elastic-wave velocities of drill-core specimens with mineral compositions and textures of elastic rocks at Niger Delta, Nigeria, can be useful for identifying large zones of high porosity or high clay content (such as some fault zones, or the clay-rich haloes surrounding known uranium ore bodies). The overall objective of this study is to identify zones of high porosity and high clay contents using elastic-wave velocities $V_{p}$ and $V_{s}$, and the ratio $V_{p} / V_{s}$. Thin sections were studied, and measurement of $V_{p}, V_{s}$, and porosity were made from cylindrical core specimens representing the Niger Delta Agbada Formation. Multiple linear regression has been employed to determine $11 V_{p}$ and $11 V_{s}$, and the ratio $V_{p} / V_{s}$ as a function of porosity $(\phi)$ and clay fraction (Fc) for all specimen from the study area. The seismic velocities $V_{p}$ and $V_{s}$, and the ratio $V_{p} / V_{s}$ for $A g b a d a$ sediment are found to be influenced by changes in porosity more strongly than by changes in clay content by a factor of approximately four. For clay fractions less than 0.15 , simple linear relationships appear to exist between the reciprocal velocities $l / V_{p}$ and $1 / V_{s}$, and the ratio $V_{p} / V_{s}$, and porosity.

Keywords: Compressional, shear velocity, porosity, permeability, clastic rock
\end{abstract}

\section{INTRODUCTION}

In addition to conventional compressionalwave surveys, widespread use is now being made of shear-wave velocities in seismic surveys. A number of workers in recent years have described methods for obtaining such data. They have demonstrated the importance of the ratio of compressional- to shear-wave velocity $V_{p} / V_{s}$ in interpreting field data in terms of lithology and texture, and as an indicator of the presence of hydrocarbons in oil exploration. Field methods for obtaining shear-wave as well as compressionalwave data for the purposes of lithological identification have been described by a number of authors like [1-3]. [4] studied means for determining rock lithology and porosity from $\mathrm{Vp}$ and Vs laboratory measurements.

[5] applied geostatistical techniques to relate transit times from surface seismic reflection to porosity measurements from wells, and compared the results to those derived from linear regression by [6-11]. [12] investigated the effect of changes in clay content on $\mathrm{Vp} / \mathrm{Vs}$ in clastic silicate rocks.

Nig. J. Pure Appl. Phys. (2005) Vol. 4 pp 82-89. Printed in Nigeria, ISSN 1596-0862. E-mail: nipapfuta@vahoo.com. For rights of reproduction and web access, contact African Journals Online, $U K, \quad w w w . i n a s p . a j o l / j o u r n a l s / n j p a p$
[13] presented work-relating petrophysics to porosity and velocity. They developed a petrophysical classification of siliciclastics to predict lithology and porosity from seismic velocity. They presented results for $V p / V s$ vs porosity. In their work they fit linear and polynomial trends to the laboratory data; their results show an increase of $\mathrm{Vp} / \mathrm{Vs}$ with porosity.

Thin sections were studied, and measurement of $\mathrm{Vp}, \mathrm{Vs}_{\mathrm{s}}$ and porosity were made for 40 core samples representing both the Niger Delta clastic rocks and the underlying basement material. Permeability measurements were made on 10 samples from two of the boreholes.

The dominant lithostratigraphic succession in the area discussed by [14] is a marine and monotonous marine shale (Akata Formation), followed by interbedded shallow-marine and fluvial sands, silts and clays (Agbada Formation, and a continental sand section, Benin Formation (Figure 1).

The degrees of compaction and cementation of the Agbada Formation, according to [15], is made up of deposit of five sub-environments: fluviatile; backswamp and lagoonal sediments; barrier bar sand; barrier foot (interbedded sand, silt and clay); marine clay and transgressive deposits.

\section{MATERIALS AND METHODS Geophysical Measurement \\ The well information used for this study} describing the Agbada Formation is an area of $6 \mathrm{~km}$ by $5 \mathrm{~km}$, slightly larger than the 3D seismic data set. The area contains 20 Vertical Seismic Profiling 
(VSP) points, including core samples, porosity-

(Figure 2).

permeability measurements and wireline logs

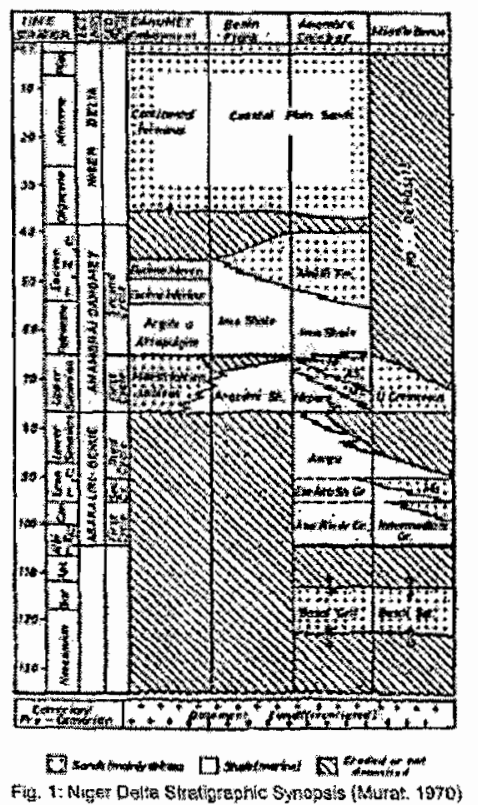

A total of three wells were selected for petrophysical measurements. All of these wells are located inside the well control area for the study. The core samples were $50 \mathrm{~mm}$ in diameter and approximately $75 \mathrm{~mm}$ in length.

The bulk densities of water-saturated specimens were calculatèd after they were weighed. The specimens were dried for 24 hours in a vacuum at a constant temperature of $800 \mathrm{C}$. They were again weighed and the densities calculated. The volume of water removed during drying was used in calculating the porosity of each sample. The accuracy in measuring the fractional perosity is estimated to be approximately 0.002 .

The compressional- and shear-wave velocities were recorded from the conventional seismic reflection data technology. The compressional and shear data set were used to show how these properties are distributed through the reservoir interval.

\section{RESULTS AND DISCUSSION Preliminary studies \\ The lithological factors that might be expected to affect elastic-wave velocities in rocks from the Niger Delta are clay content, porosity and permeability. Petrophysical measurements of porosity, density, Vp, permeability, and clay content are plotted as function of depth for the three Wells numbered $\mathrm{A}, \mathrm{B}$ and $\mathrm{C}$. Their detailed variations are shown in Figures 3,4 and 5.}

\section{Density}

The densities of the layers studied vary between 2434 and $2508 \mathrm{~kg} / \mathrm{m} 3$, although there are significant local deviations from these values. In general, the values of density show little significant depth or stratigraphic variations. Changes in the clay contents also appear to have no observable effect on

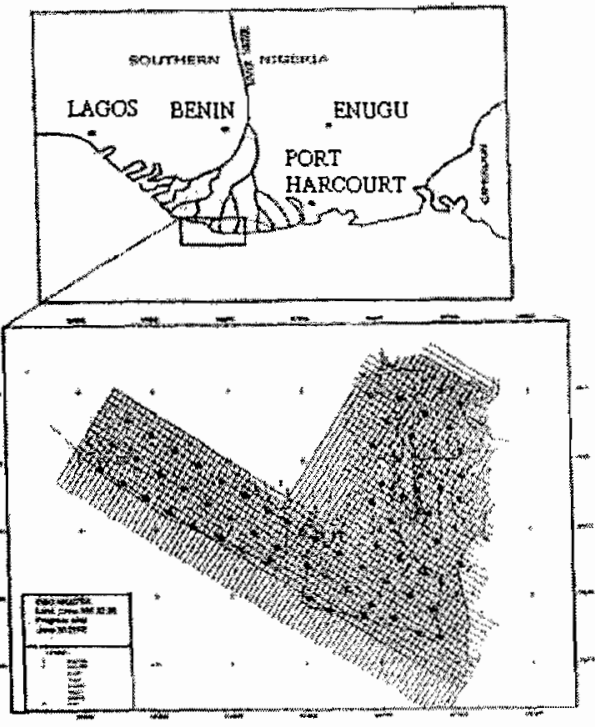

Fig. 2. Map of Niger Delta showing the location of study area within the limit of survey and well control points

the values of measured density, but an increase in clay usually occurs with a concomitant increase in porosity.

\section{Claycontent}

Clay fractions vary mainly between 0.05 and 0.15 but range from nearly 0 to 0.40 . In general, the correlation between clay fraction and $\mathrm{Vp}$ shows that an increase in clay content results in a marked decrease in Vp. It should be noted that as the clay fraction increases, the porosity appears to increase by only a small amount. Figures 3,4 and 5 indicate a general but slight increase in clay content with depth in the upper part of each well, with little overall change in the lower portion.

\section{Grain size}

The various stratigraphic units at study area are delineated mainly by grain size (Figure 1). There is no difference in $\mathrm{Vp}$ with stratigraphic position as shown in Figures 3,4 and 5. Also, Figure 7 shows no differential clustering from plots of $\mathrm{Vp}$ vs porosity for various grain sizes indicating that grain-size variation has little to no effect on $\mathrm{Vp}$ in the Agbada Formation

\section{Porosity and Permeability}

The calculated porosities are between 0.05 and 0.10 . Figures 3,4 and 5 do reveal a slight variation of porosity with depth, and a direct relationship between $V p$ and porosity. Figure 6 demonstrates clearly that $\mathrm{Vp}$ decreases as porosity increases.

The permeability is locally highly variable but, in general, appears to decrease with depth despite the uniform porosity (Figures 4 and 5).

Linear regression analyses of the preliminary results for layers from each of the wells are shown in Tablel. The overall changes in these parameter-density, porosity and 


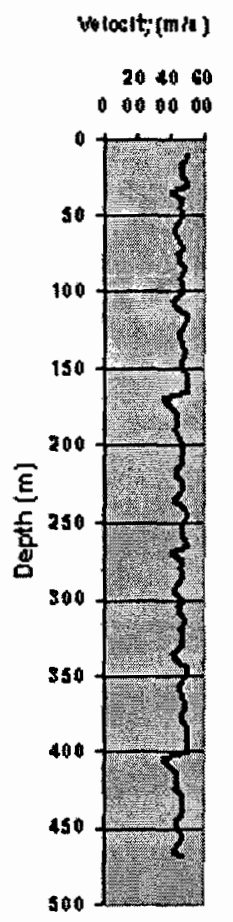

Donult (gtm) Cr: Denult; (gitm) ind

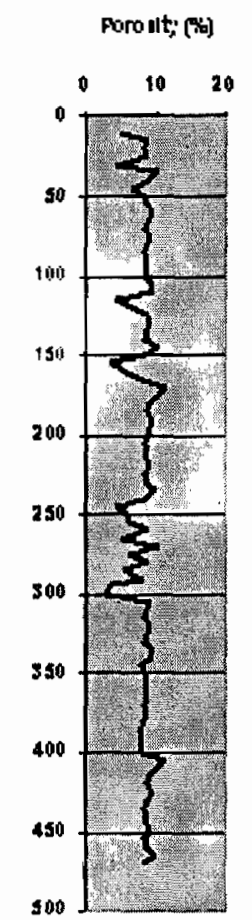

0; contant(i)
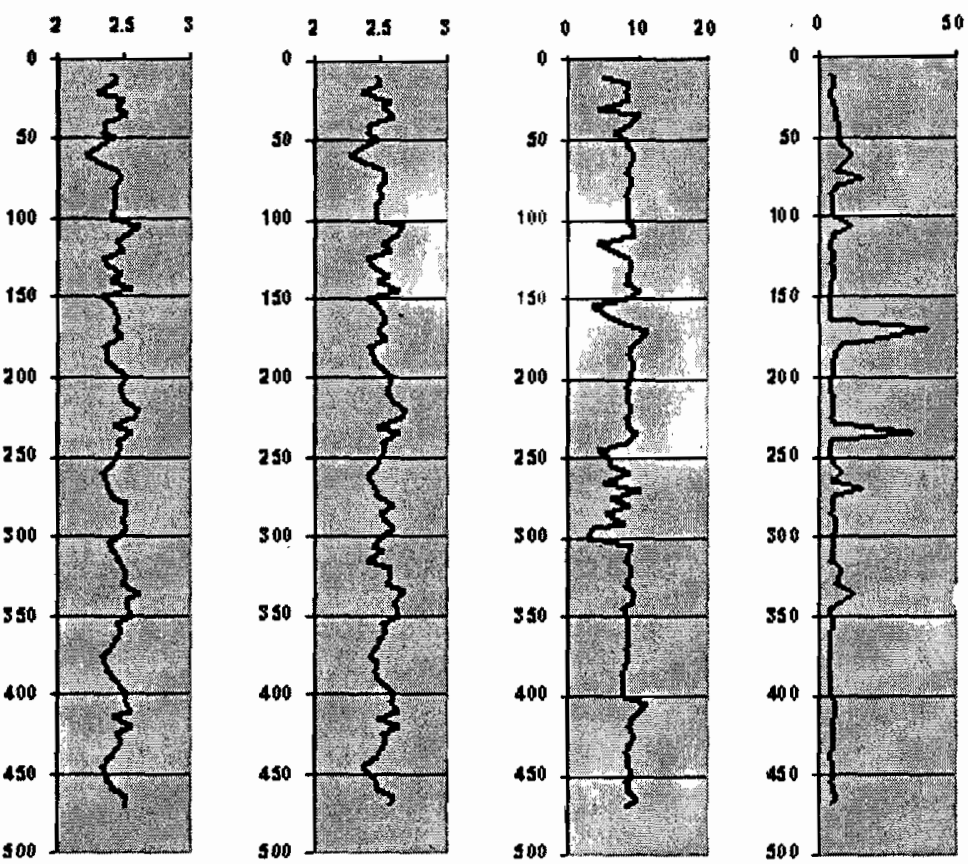

Fiz 3: R wave velocity, Whateraturated density fordy and wet sanples,

Porsity and Cay Content for Che sanples from Wel A
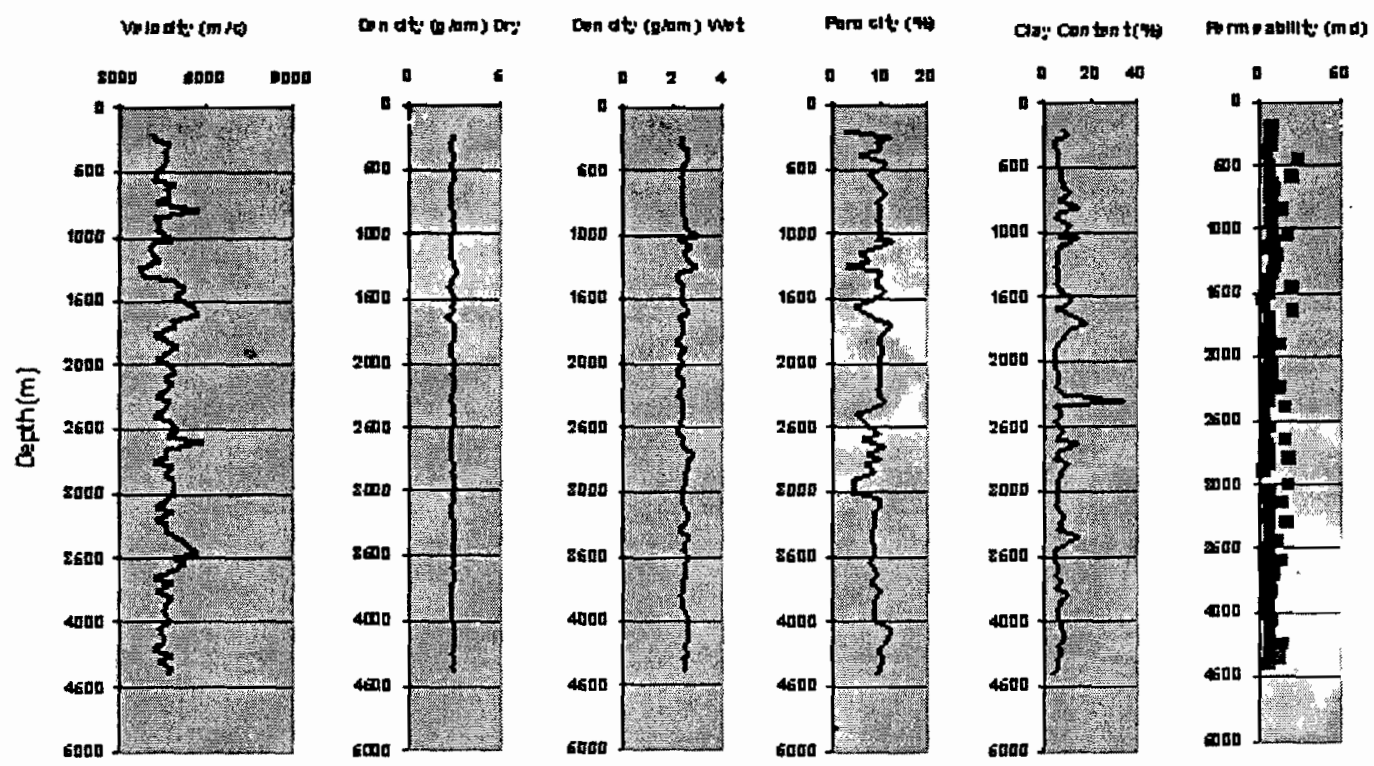

Fie 4: Pusweve locity, Watersaturated density for dy and wet samples, Phosidy, Chy Content and permeab tity for Core samples fiom Weil B. 
Olowo, te $\mathrm{A}$. Elisuc-wave and related properties of clastic rocks from a part of Niger delta, Nigeria

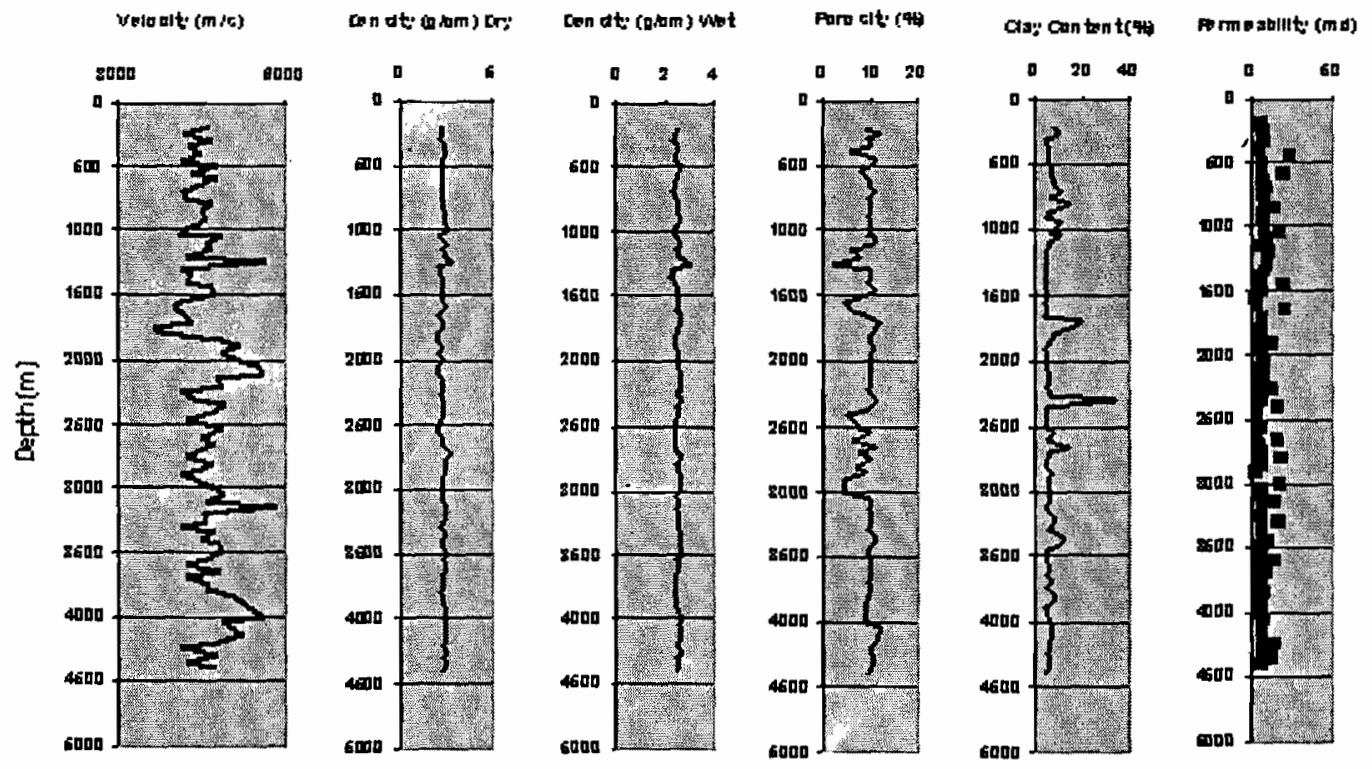

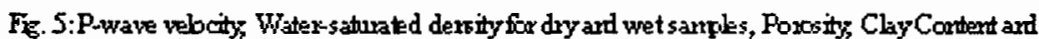
penred inf for Core samples from WellC.

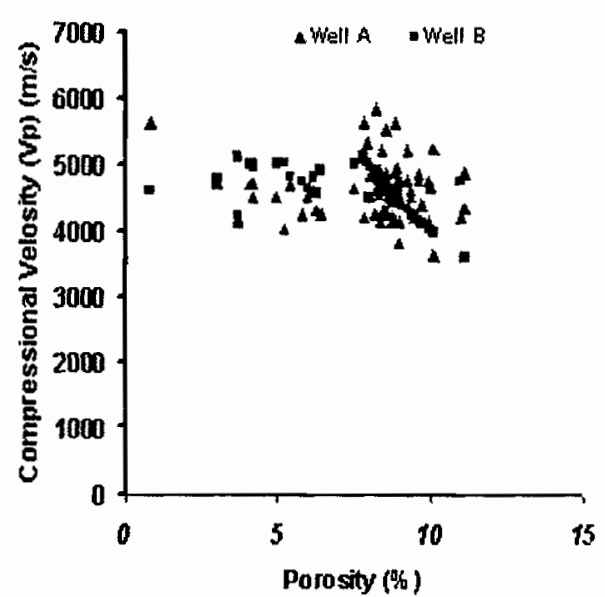

Fig. 6a: Plot of $V p$ against Porosity for Well $A$ and $B$.

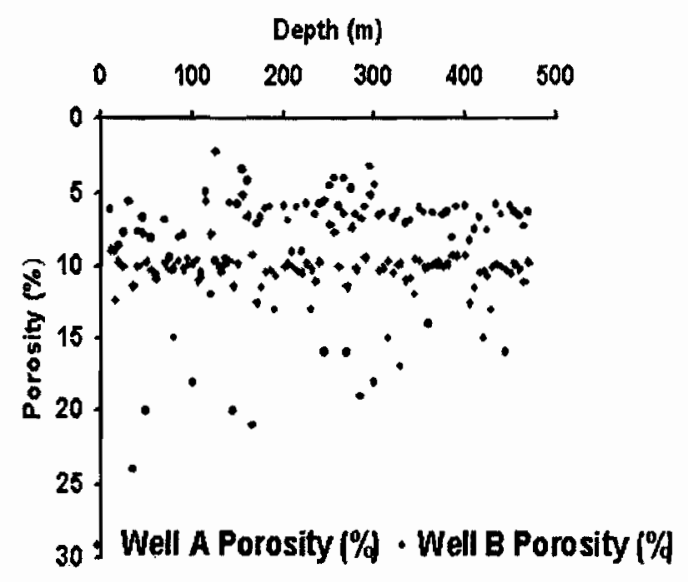

Fig. 6b: Plot of Porosity against depth for Well A and Well B 
Olowokere M. T.: Elastic-wave and related properties of clastic rocks from a part of Niger delta, Nigeria

Table 1. Table showing the relationship between seismic properties, porosity and net overburden pressure.

\begin{tabular}{|c|c|c|c|c|c|c|c|c|c|c|c|c|}
\hline $\begin{array}{c}\text { Net } \\
\text { Overburden } \\
\text { Pressure } \\
\text { (psi) }\end{array}$ & 50 & 100 & 150 & 200 & 250 & 300 & 50 & 100 & 150 & 200 & 250 & 300 \\
\hline Porosity \% & \multicolumn{6}{|c|}{$\mathrm{V}_{\mathrm{p}}(\mathrm{m} / \mathrm{s})$} & \multicolumn{6}{|c|}{$\mathbf{V}_{s}(\mathbf{m} / \mathrm{s})$} \\
\hline 3 & 2450 & $24 \overline{58}$ & 1268 & 2365 & 2255 & 2230 & 1155 & 1150 & 1140 & 1135 & 1120 & 1100 \\
\hline 6 & 2380 & 2360 & 2345 & 2285 & 2265 & 2250 & 1115 & 1120 & 1090 & 1080 & 1075 & 1070 \\
\hline 9 & 2205 & 2200 & 2190 & 2150 & 2080 & 2065 & 1050 & 1043 & 1035 & 1020 & 1015 & 1005 \\
\hline 12 & 2195 & 2180 & 2175 & 2150 & 2130 & 2090 & 1045 & 1043 & $\mathbf{1 0 3 0}$ & 1036 & 1007 & 990 \\
\hline 14 & 2080 & 2060 & 2050 & 2040 & 1960 & 1950 & 1025 & 1016 & 1000 & 995 & 980 & 975 \\
\hline 16 & 1950 & 1955 & 1925 & 1928 & 1825 & 1924 & 1045 & 1040 & 959 & 956 & 950 & 930 \\
\hline
\end{tabular}

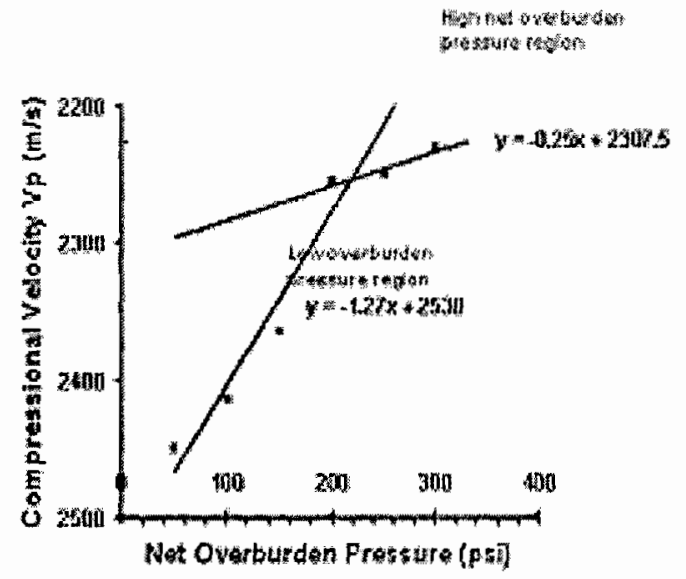

Fig. 7a: Graph stowing the relationethip bewern Compressional wave velocity vo and Not overburden pressure

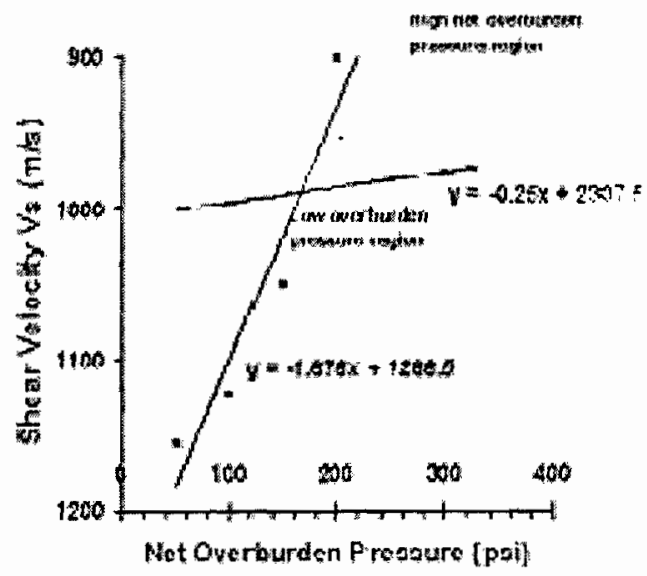

Fig. Io: Graph showing the retationship setween Shear wave welocity Vs and Not Onerburcen Pressure:
Vp with depth are not dramatic, as it is evident from the low magnitude of the slopes from the regression. Grain size has little to no effect on Vp. Porosity and clay content, however, serve as important controls on the rocks' seismic velocities.

Elastic-wave velocities

$V p$ and Vs for typical water-saturated Agbada Formation of the Niger Delta specimens are plotted as functions of net overburden pressure from 50 to 300 psi in Figure 7 for sample porosities in the range 0.03 to 0.16 . The pronounced changes in slope for $V p$ and $V s$ at low net overburden pressure probably result from the closure of microcracks of small aspect ratios at these stresses. A statistical analysis of $\mathrm{Vp} / \mathrm{Vs}$ ratio for all specimens tested (Fig. 8) indicates that in the range of net overburden pressure from 50 to $300 \mathrm{psi}$ there is only a small increase in $\mathrm{Vp} / \mathrm{Vs}$. This overall change (an increase of 0.07 percent) is considerably less than the 0.8 percent uncertainty based on the 
Olowokere M. T.: Elastic-wave and related properties of clastic rocks from a part of Niger delta, Nigeria

precision of the experimental results. [1] showed in their study that once the microcracks of small aspect ratios in a porous sandstone are closed, $\mathrm{Vp} /$ $\mathrm{Vs}$ is relatively insensitive to further changes in net overburden pressure (as might be caused by an increase in net overburden pressure 50 to $300 \mathrm{psi}$.

[6] predicts a linear relationship for $\mathrm{Vp} /$ Vs as a function of porosity proposed for watersaturated porous rocks from his empirical timeaverage relationship. Multiple linear regression as functions "it porosity $(\phi)$ and clay fraction (Fc) for a total of 40 rock samples from the Agbada Formation are determined. The velocities used are those measured at net overburden pressure of 300 psi (to avoid the effects of the presence of microcracks). The regressions determined for $1 / V_{p}$, 1/ $V_{s}$ and $V_{p} / V_{s}$ are shown in Table 2. The standard deviations of the regression coefficients for $\phi$ and $F c$ and multiple correlation coefficient $r$, are as listed in Table 2 . These regression coefficients are significant at the 0.1 percent level and that regression of the dependent variable in each case $\phi$ and Fc accounts for a significant amount of the variation in the dependent variable.

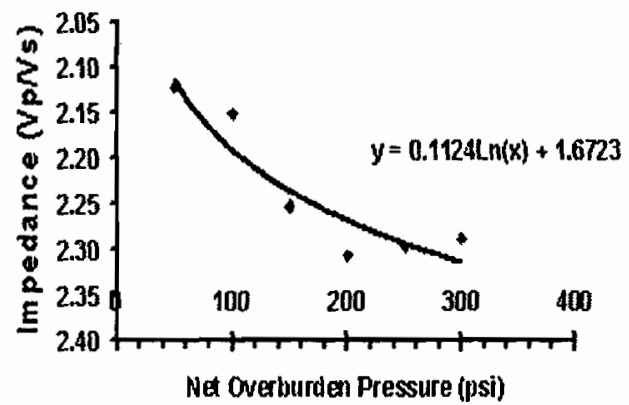

Fig. 8: Graph showing the relationship between Impedance (Vp/Vs) and Net Overburden Pressure (psi)

Table 2: Regression table for Parameters $1 / V_{p}, 1 / V_{s}$ and $V_{p} / V_{s}$ as a function of Porosity

\begin{tabular}{|c|c|c|c|}
\hline Parameter $\mathbf{y}$ & Slope $\mathrm{a}_{\mathrm{o}}$ & Intercept $\mathrm{a}_{1}$ & Regression Coefficient $\mathrm{R}^{2}$ \\
\hline \hline $\mathbf{1} / \mathbf{V}_{\mathrm{p}}$ & 0.034 & 4.00 & 0.95 \\
\hline $\mathbf{1} / \mathbf{V}_{\mathrm{s}}$ & 0.002 & 4.00 & 0.93 \\
\hline $\mathbf{V}_{\mathrm{p}} / \mathbf{V}_{\mathrm{s}}$ & 0.015 & 2.10 & 0.85 \\
\hline
\end{tabular}

The relationships are shown in Table 3 for $1 / \mathrm{V}_{\mathrm{p}}, 1 / \mathrm{V}_{\mathrm{s}}$ and $\mathrm{V}_{\mathrm{p}} / \mathrm{V}_{\mathrm{s}}$ in the porosity range 0 to 0.15 and for clay fractions from 0 to 0.3 . It is seen that increases in $\phi$ and $F_{c}$ result in increases in magnitude of all three parameters $1 / V_{p}, 1 / V_{s}$ and
$\mathrm{V}_{\mathrm{p}} / \mathrm{V}_{\mathrm{s}}$. It is clear also that these parameters are more sensitive to changes in porosity than to those in clay content by a factor of approximately four. This conclusion is similar to those of [16] and [12].

Table 3: The relationships for $1 / V_{p}, 1 / V_{s}$ and $V_{p} / V_{s}$ in the porosity range 0 to 0.15 and for clay fractions from 0 to 0.3 .

\begin{tabular}{|c|c|c|c|}
\hline Porosity (\%) & Clay Fraction (\%) & $1 / \mathrm{Vp}$ & $1 / \mathrm{Vs}$ \\
\hline 3 & 5 & 4.1 & 8.7 \\
\hline 6 & 10 & 4.1 & 8.9 \\
\hline 9 & 15 & 4.2 & 9.5 \\
\hline 12 & 20 & 4.1 & 11.1 \\
\hline 14 & 25 & 4.4 & 10.2 \\
\hline 16 & 30 & 4.5 & 10.3 \\
\hline
\end{tabular}

A study of the relationships for $1 / \mathrm{V}_{\mathrm{p}}, 1 /$ $V_{s}$ and $V_{p} / V_{s}$ have been ploted in Figures 9 and 10 as functions of porosity for the samples baving a clay fraction less than 0.15 . The correlation coefficients shown in Figures 9 and 10 indicate that each of the regressions is significant at better than the 1 percent level. The increases in $1 / \mathrm{V}_{p}, 1 / \mathrm{V}_{s}$ and $V_{p} / V_{s}$ with increasing porosity are similar in magnitude to those reported by [4]. 

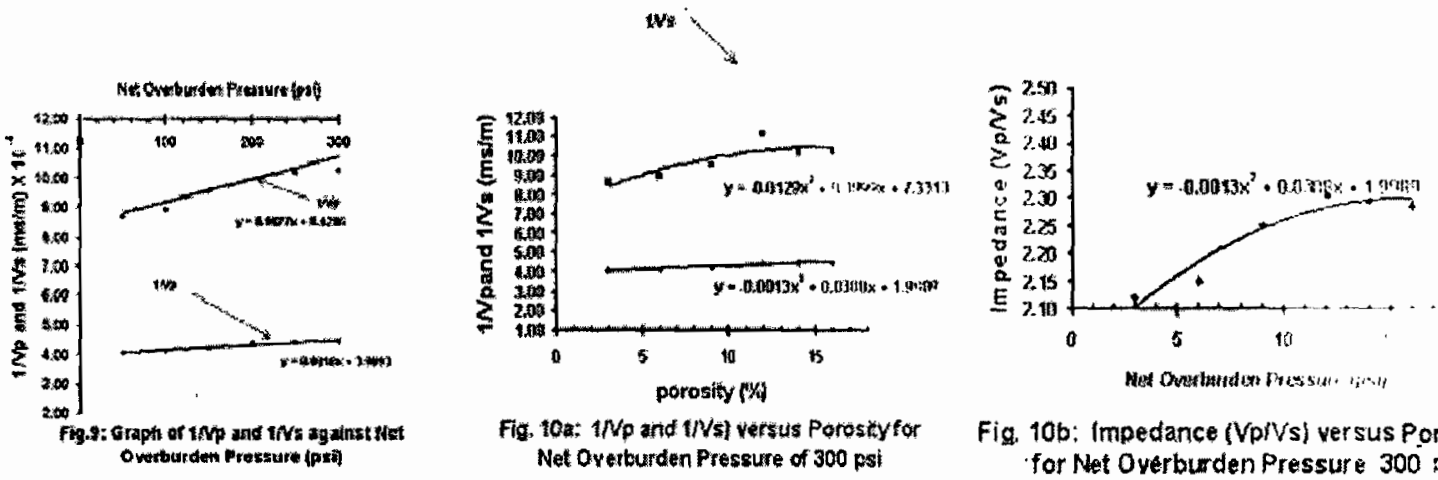

Fig 10b; Impedance (Vp/vs) versus Porosit: for Net Overburden Pressure $300 \mathrm{Fe}$

\section{CONCLUSION}

The main feature of the Agbada Formation of the Niger Delta is variation in grain size along with considerable variation in clay content. However, neither of these features appears to affect seismic velocities.

Marked variations in velocities $V_{p}$ and $V_{s}$ and the ratio for $\mathrm{V}_{\mathrm{p}} / \mathrm{V}_{\mathrm{s}}$ of the Agbada Formation of the Niger Delta are functions of changes in porosity and clay content. Increases in both clay and porosity cause reductions in $\mathrm{Vp} / \mathrm{Vs}$, but clay has only about one quarter the effect of porosity in the range of porosities 0 to 0.03 and clay fraction 0 to 0.4 . For clay fractions less than 0.2 , simple linear relationships appear to exist between the reciprocal velocities $1 / \mathrm{Vp}$ and $\mathrm{Vs} /$ and the ratio / and porosity. The relationships between seismic velocities and net overburden pressure show that it is linear; seismic properties increase faster (high slope) in low net overburden pressure regions and slower (low slope) in high net overburden region.

\section{ACKNOWLEDGEMENT}

The author acknowledges the assistance provided by the Department of Petroleum Resources for data coliection. I thank $\mathrm{Mr}$ Olisa Benson. for the computer work during the data analysis stage.

\section{REFERENCES}

[1]. Tatham, R.H and Stoffa, P.L., Vp / Vs, -A Potential Hydrocarbon Indicator Geophysics Vol. 41, 837-849, 1976.

[2] Polskov, M.K., Brodov L.J., Mironova, L.V., Michon, D., Garotta, R., Layotte, P.C. and Coppens, F., 1980, Uilisation combinee des omdes longitudinales et transversals en sismique reflexion: Geophys. Props. Vol. 28, 185-207.
S-Wave Seismic Data: a New Method for Delecting Gas Reservoirs: Geophysics Vol. 49, 1420-1431.

[4] Domenico, S.N., 1984, Rock Lithology and Porosity Determination from Shear and Compressional Wave Velocity: Geophysics Vol. 49, 1188-1195.

[5] Doyen, P.M., 1988: Porosity from Seismic Data, a Geostatistical Approach: Geophysics, Vol. 53, No 10 p 1263-1265.

[6] Wyllie, M.R.J., Gregory, A.R. ann Gardner, L.W.:Elastic Wave Velocitics in Heterogeneous and Porous Media: Geophysics Vol. 21, No. 1 41-70 (1956).

[7] Wyllie, M.R.J., Gregory, A.R. and Gardner, L.W., Studies Elastic Wave Attenuation in Porous Media: Geophysics Vol. 27, No. 5 p 569580 (1962).

[8] Eberhart-Phillips, D., D-H. Han, and M.D. Zoback, 1989, Emprical Relationships among Seismic Velocity, Effective Pressure, Clay Conten in Sandstones: Geophysics Vol. 54, No 1 p 82-89.

19) Klimmento.. I: The Effects of Porosity Permeability-Clay comtent on the Velocity of Compressional Waves: Geophysics, Vol. 56, No 12 , p. $1930-1939$ (1991)

[10] Marion, D., A. Nur, H. Yin, and D. Han: Compressional Velocity and Porosity in Sand-Clay Mixtures: Geophysics, Vol. 57, No. 4, p. 554-563 (1992).

[11] Mavko, G., and R. Nolen-Hoeksema: Estimation of Seismic Velocities at Ultrasonic Frequencies in Partially Saturated Rocks: Geophysics, Vol. 59, No. 2, p. 252-25s (1994). 
Olowokere M. T.: Elastic-wave and related properties of clastic rocks from a part of Niger delta, Nigeria

[12] Castagna, J.P., batzle, M.L. and Eastwood, R.L.: Relationships between Compressional-Wave and Shear-Wave Velocities in Clastic Silicate Rocks: Geophysics Vol. 50, 571-581 (1985).

[13] Vernik, L., and A. Nur: Petrophysical Classification of Siliciclastics for Lithology and Porosity Prediction from Seismic Velocities: AAPG Bulletin, Vol. 76, No 9, p 1259-1309 (1992).

[14] Short, K. C. and A. J. Stauble: Outline of
Geology of Niger Delta; Amer. Assoc. Petrol. Geol. Bull., Vol.57, p. $761-779$ (1967).

[15] Weber, K.J. and Daukoru, E.M.: Petroleum Geological Aspects of the Niger Delta Nigeria, Jour. Min. Geol., Vol.12 No. (1/2), p.9:22, (1975)

[16] Tosaya, C. and Nur, A.: Effects of Diagenesis and Clays on Compressional Velocities in Rocks: Geophys. Res. Lett. 9, 5-8 (1982). 